\title{
Access to Business Development Support Services and Performance of Youth- Owned Enterprises in Tanzania
}

\author{
Neema Mori ${ }^{1}$
}

\begin{abstract}
We investigated a sample of 3,098 randomly chosen youth-owned enterprises (YOEs) in Tanzania and studied their access to business development support (BDS) services. YOEs are defined as enterprises owned and run by young entrepreneurs, aged between sixteen and thirty-five, according to the Tanzanian definition of youth. We analyzed which BDS services affect the performance of YOEs in terms of (i) number of employees, (ii) whether the enterprise keeps financial records and (iii) the entrepreneurs' perception of the performance of their enterprises. With the support of the resourcebased view, we found that access to expert advice is positively associated with a YOE's number of employees and their ability to keep financial records. We also found that access to business management training and entrepreneurship training positively influences financial record keeping and enterprises' perceived performance. Overall, we conclude that the resources that young entrepreneurs obtain through their access to BDS services are crucial for their enterprises.
\end{abstract}

Keywords: youth, business development services, YOEs, Tanzania.

\section{INTRODUCTION}

Young people's participation in owning and running small and medium-sized enterprises (SMEs) forms part of youth entrepreneurship, which is a means of improving youths' livelihoods (Niemelä and Häkkinen, 2014). Within the framework of efforts and strategies aimed at creating jobs for young people, entrepreneurship and youth-owned enterprises (YOEs) are becoming acceptable as an important means and a valuable strategy for creating jobs and ensuring the economic independence of young people (De Gobbi, 2014; Sukarieh and Tannock, 2008). It is an innovative approach for integrating youth into today's changing labor markets. Although YOEs play a crucial role in driving economic development and creating jobs, there is little research

\footnotetext{
1 Neema Mori, Ph.D., Department of Finance, University of Dar es Salaam Business School, Dar es Salaam, Tanzania. Research Fellow, Norwegian Centre For Microfinance Research (NOCMIR), University of Agder, Kristiansand, Norway. UDBS Building Wing A, P.O. Box 35046, Dar es Salaam, Tanzania. Tel.: +255767065698. E-mail: neema.mori@gmail.com.
} 
examining SMEs and entrepreneurship from the perspective of youth. Young people are mostly treated as part of the general adult population, while their specific needs and particular entrepreneurial potential, the high unemployment rate among them and their critical contribution to economic and social progress are underestimated.

Access to education and business development support (BDS) services, such as entrepreneurship training, is important if younger adults are to be successful in running their enterprises (Shelley, 2014). Chigunta (2002) suggests that YOEs need to access BDS and must know how to, among other things, develop business plans, manage their businesses, manage their finances (budgeting), manage their time, market their goods and sell them. All these aspects are essential for enhancing the performance of their enterprises. Despite the fact that access to BDS is important, there is little knowledge of how these services enhance the performance of businesses. There is some literature that shows how important these services are and how SMEs access finance but few studies have examined their effects on performance. This study seeks to fill this gap by examining the extent to which access to different forms of BDS affects enterprise performance. We ask the following question: What are the effects of BDS services on the performance of YOEs?

The focus on YOEs is important because the young form the basis of a society's future. Thus, many nations are recognizing the importance of youth to their development and are formulating policies and programs to guide them (Koe, 2013). The global youth population is increasing, now representing $20 \%$ of the world's total population. It is further estimated that the youth population will peak at 1.5 billion in 2035, increasing most rapidly in Sub-Saharan Africa, by $26 \%$.

Youth is a crucial time in life when young people start realizing their aspirations, assuming their economic independence and finding their place in society. The global jobs crisis has exacerbated the vulnerability of young people in terms of (i) higher unemployment, (ii) lower-quality jobs, (iii) greater labor market inequalities, (iv) a longer and less secure school-towork transition, and ( $v$ ) increased detachment from the labor market (De Gobbi, 2014). The principal challenge for many African economies, including Tanzania, is to find productive employment for the 7 to 10 million new entrants to the labor force annually.

Tanzania is facing a youth unemployment crisis rivaled by few other nations in the world. Estimates show that between 650,000 and 750,000 Tanzanian youths enter the labor market every year ( $\mathrm{Ng}^{\prime}$ habi, 2013). The latter study further shows that the formal private sector employs most of the youths, with approximately $14 \%$ employed in this sector. Manacorda and 
Kondylis, (2006) illustrate that in urban areas the aggregate state of the local labor market is a major determinant of a young individual's labor market outcome.

Owning, starting and operating their own enterprises is an important channel for youths, allowing them to create employment for themselves and others (Garba and Djafar, 2013). A report by the Ministry of Trade in Tanzania (URT, 2012), shows that $47 \%$ of SME owners are younger than 35 years old. This implies that the number of YOEs is increasing. It is therefore apparent that youths are an important resource and have an important role to play in the economic development of the country. This means that examining the performance of their enterprises is crucial as their survival and success have major implications for both policy and theory.

We use the resource-based view (RBV) as our theoretical perspective because the resources that the young entrepreneur obtains through accessing BDS services are crucial in enabling his/her enterprise to perform well. The RBV further argues that differences in performance between enterprises may be best explained through differences in their human and financial assets and resources and their application, rather than through differences in industry structures. We therefore use this theory to study whether YOEs with access to BDS resources perform better than those without such access.

The BDS services examined are expert advice, business management training, entrepreneurship training, support with developing a business plan and technical skills. The performance/growth aspects examined are the number of employees, whether financial records are kept and perceived performance.

We tested our hypothesis using data from the MSME (micro, small and medium-sized enterprises) baseline survey ${ }^{1}$. These data were collected in 2010. The dataset covers the whole of Tanzania. We extracted data on youth entrepreneurs between 16 and 35 years of age as of 2010. The resulting youth dataset had 3098 observations.

The findings support a relationship between BDS access and YOEs' performance. We find access to expert advice to be positively associated with a YOE's number of employees and ability to keep financial records. We also find business management and entrepreneurship training to positively influence financial record keeping and enterprises' perceived performance. These results show that the resources that young entrepreneurs obtain by accessing BDS services are key to their enterprises' performance.

The rest of the paper is organized as follows. The next section presents the literature on young entrepreneurs and their enterprises. This is followed

1 The MSME baseline survey data were obtained from the Financial Sector Deepening Trust. We thank them for making this dataset available to us. 
by a section covering the theory. Afterwards, we present the methodology used in the study, followed by the results and discussion. The conclusion and implications are presented in the last section.

\section{Young entrepreneurs and their enterprises}

Young entrepreneurs and their enterprises are among the more recently recognized sources of income, new jobs and economic dynamism in developed countries (De Gobbi, 2014; Olomi and Nchimbi, 2009). The literature further suggests that YOEs are a bottom-up method of generating income and selfreliance and an innovative path to earning a living and caring for oneself (Green, 2013). Studies further show that young entrepreneurs and the performance of their enterprises may vary according to the entrepreneur's age. Chigunta (2002) and Schoof (2006) consider three transitional categories of young entrepreneurs based on their age. First are the pre-entrepreneurs who are between 15 and 19 years old. This, according to them, is the formative stage during which younger youths are often in transition from the security of the home or education to the workplace. Second are the budding entrepreneurs, who are between 20 and 25 years old. This is the growth stage by which point, youths and their enterprises have gained some experience, skills and capital to enable them to continue in business. Young entrepreneurs at this stage have three enterprise pathways: remaining stuck in the marginal activities in which they are currently engaged, going out of business, or running their enterprises successfully and looking for ways to grow (Chigunta, 2002). The final stage is the emergent entrepreneurs, who are between 26 and 29 years old. This is the prime stage, by which point young entrepreneurs have valuable business experience and are more mature than those in the lower age groups.

However, Chigunta (2002) further points out that this kind of categorization only serves as a broad suggestion, as transitions differ from country to country and from business sector to business sector. Lewis and Massey (2003) further suggest that the needs and challenges facing young entrepreneurs vary according to age, level of readiness to engage in business, and intention to be enterprising. This implies that BDS for young entrepreneurs and their enterprises will have different effects, depending on their stage of development and these other differences.

In Tanzania, youths are defined as persons aged 15 to 35 (Olomi and Nchimbi, 2009; URT, 2007). Our paper uses this definition and further categorizes youths into two groups: younger youths aged 15 to 24 and older youths aged 25 to 35 (Olomi and Nchimbi, 2009). In this way we recognize that youths are a heterogeneous group with different challenges and needs. 
For instance, younger youths are more likely to be single, to have not worked before and to still live with their parents. Those who have YOEs are most likely to engage in a narrow range of activities, mostly informal trading and activities that are relatively easy to engage in. By contrast, older youths are likely to be more independent, to have families and to have more stable businesses (Olomi and Nchimbi, 2009). Based on this categorization, this paper examines how the two groups' enterprises perform.

The Global Entrepreneurship Monitor, a report that measures, analyzes and reports on entrepreneurial activity in 43 countries, shows that people aged between 25 and 34 are more likely to start owning and running enterprises than other age groups (Amorós and Bosma, 2013). The reasons suggested for this are the following: youths in this age group have developed enough competence to manage a new business through work experience; they may have accumulated other resources, such as relevant networks, personal savings, or access to financial resources; they may have recognized opportunities relating to their experience or may have decided to work independently after having been employed; they are less likely to be established in a career that may offer a higher salary or position; they may have fewer personal financial obligations, such as major loans and families to support. All these factors, together with high youth unemployment, may motivate them to own and run their own enterprises. The aforementioned report further shows these youths to have less to lose than their older counterparts.

The literature cites various reasons why young entrepreneurs are important to both literature and practice. Green (2013) and Schoof (2006) mention the following: they provide a source of employment for themselves and other youths; they create a sense of meaning and belonging by positioning themselves within the economic mainstream; starting a business addresses some of the socio-psychological problems and the delinquency that can result from joblessness; they are able to develop new skills and experiences that can then be applied to other challenges in life; they promote innovation and resilience in themselves, due to the fact that they are able to respond quickly to new economic opportunities and trends.

YOEs are also important in themselves. The literature argues that promoting YOEs changes youths' attitudes and values so that they see selfemployment as a viable means of earning a living and prospering (Green, 2013). YOEs not only raise the degree of competition in the product market, but also create linkages between young entrepreneurs and other economic actors, through subcontracting, franchising, and so on.

Various studies have looked at the performance of YOEs. Fairlie (2005), for example, examines entrepreneurship and earnings among YOEs in USA. 
The study assesses whether youths who own and run enterprises earn more than employed youths. The results show that male youths who run businesses earn more than employed male youths. In contrast, young women running businesses earn less than their employed counterparts.

Amorós and Bosma (2013) show that YOEs run by youths aged 25 to 34 perform better than those owned by younger youths (aged 18 to 25 ) and this is more apparent in high-income countries. Different levels of participation in both secondary and tertiary education are one reason for this tendency. In lowincome countries, most young people do not complete secondary education and thus tend to start businesses earlier, with a lower level of education, whereas in high-income countries education seems to be positively related to the performance of YOEs (Amorós and Bosma, 2013). Walstad and Kourilsky (2008) investigate the attitudes towards education and the knowledge of entrepreneurship among black youths in the USA. The results show that black youths have a strong desire to start businesses, want more teaching of entrepreneurship in their schools, and believe that successful entrepreneurs have a responsibility to give back to their community. The authors further point out that black youths who own and run businesses face greater challenges in accessing role models and business support or knowledge than their white counterparts.

Kilonzo (2012) examines factors that enhance YOEs' performance, conducting a survey of 465 YOEs in the Machakos District of Kenya. The performance of the YOEs is measured in terms of sales level, sales growth rate, cash flow, gross profit margin, return on investment and retained earnings. The results indicate that measures of perception, namely the need to achieve, self-efficacy, moderate risk taking, and the perception of opportunities, are important predictors of YOEs' performance. In addition, the author finds a positive relationship between financial resources and YOE performance, and she recommended that more financial resources should be made available to YOEs to enable them to improve their business performance.

Wanjiru (2013) also investigates the factors influencing the performance of YOEs, specifically examining the influence of socio-cultural factors, education, training and skills, and access to finance. Performance is measured using sales, number of employees and net income. The study sample is 122 YOEs in Kenya. The results show that socio-cultural factors, mainly religion and family size, affect the performance of YOEs. The study further establishes that education, training and skills affect the performance of enterprises. The author finds the majority of the young entrepreneurs in her sample (73\%) to have never received any business support services, while the remainder report a positive difference to their enterprise performance from such services. The author recommends, among other things, that YOEs should be 
able to access different kinds of BDS services, such as business management skills and entrepreneurship training, to improve their performance.

These results and recommendations are similar to those of Green (2013), who suggests that young entrepreneurs face imperfect information both before and after starting a business. The Green's report further suggests that young people may simply be unaware of the potential of entrepreneurship, their entrepreneurial aptitude or the skills they will need in order to perform well in their enterprises. A lack of awareness and access to information on BDS may also impede the growth of their enterprises.

Finally, Berry, Sweeting and Goto (2006) examine the effect of business advice on the performance of SMEs in general. They look at the relationship between business performance and the nature and degree of a wide range of business advice used by a sample of owners/managers of 140 SMEs in the UK. The results show that an SME's use of a range of external advice is positively related to its growth rate. The business and financial management advice the SMEs had received was perceived to be helpful in terms of enterprise performance. The authors further argue that the range and nature of advice provided by external accountants, academicians and other BDS service providers are important for enhancing SMEs' performance.

These arguments demonstrate that YOEs create employment for youths and encourage the development of youth entrepreneurship. There are also some studies that have looked at young entrepreneurs and the performance of YOEs. However, most of these studies have been descriptive, looking more at the characteristics of young entrepreneurs and how they perceive the performance of their own enterprises. Except for Berry et al. (2006), who examine the performance of all SMEs in the UK, none of the reviewed studies examines the effect of BDS on YOEs' performance. In addition, the prior studies reveal that higher education is essential for YOEs' performance and therefore we argue that, since many young entrepreneurs do not have higher education, it is necessary for them to access BDS so as to gain knowledge on how to run their enterprises (Wanjiru, 2013). This study contributes to this view.

\section{THEORY AND HYPOTHESIS}

BDS comprises services that improve the performance of enterprises. These services include training in business management, entrepreneurship, and business plan development, consulting, coaching and mentoring, and the provision of advice, marketing assistance, information, technology development and transfer, and business linkages promotion (Stevenson and St-Onge, 2013). These services are resources that YOEs need in order 
to improve their daily operations, to make strategic decisions that can help them identify and service markets, to design products, to set up facilities, to seek finance, and/or to make them more competitive with other enterprises (Stevenson and St-Onge, 2013).

YOEs are more likely to access and use BDS services than others. Green, 2013 calls these services "soft support", as they are intangible services, as opposed to "hard support" such as obtaining funds, but they are still key to YOEs' performance. These services may be obtained through formal channels (colleges and BDS providers), or informally through the internet, social networks of youths or older mentors, who may use their social capital to leverage resources for aspiring young entrepreneurs (Green, 2013). Because of this, it is possible that not all young entrepreneurs will be able to access the same level and quality of services. In this case, some young entrepreneurs may have certain skills and experience that others lack and this may make them more competitive.

The RBV provides the theoretical justification of how the access to and use of BDS can enhance the performance of YOEs. The theory examines the performance of enterprises from the perspective of the internal resources that enterprises have (Barney, 1991). According to the latter author, resources are tangible and intangible assets that are tied semi-permanently to the enterprise. The literature further shows that an enterprise's tangible and intangible resources are central to explaining its performance (Wernerfelt, 1984). Examples of resources can include brand names, in-house knowledge of technology, the employment of skilled personnel, and specific business knowledge. The access and use of various BDS services are among the intangible resources that YOEs can benefit from in order to enhance their performance.

Lerner and Almor (2002) further suggest that the RBV is an appropriate theory for explaining how small enterprises are created and managed, because it best describes how the entrepreneurs themselves build their businesses from the resources and capabilities they currently possess or can acquire. Chigunta (2002) points out that there are some business support resources that youths already have and others that they can acquire. The author shows that the business skills that one should already have are the capacity to plan, communicate, market, and build and lead a team, as well as inter-personal, basic management and quantitative/analytical skills. The resources that one can access comprise specialized marketing advice/services, and training in record keeping, the law, accounting, research, technical matters, financial and information management, and so on.

Accessing these services in different ways can differentiate one entrepreneur from another and one enterprise from another. Since the 
RBV posits that performance may be best explained through the resources, assets and skills available to the enterprise, we hypothesize that there is a positive relationship between young entrepreneurs who have acquired BDS and the performance of their enterprises. Moreover, the theory predicts that entrepreneurs whose resources are superior (in this case indicated by a young entrepreneur who has accessed/received business support) will be able to ensure the superior performance of their enterprises (Peteraf, 1993, p. 180).

\section{METHODOLOGY}

\section{Data}

The empirical setting for this study is Tanzania. Tanzania has a population of 47 million and $48 \%$ of them are youths ${ }^{2}$. The number of micro, small and medium-sized enterprises (MSMEs) in Tanzania is estimated to be 3.1 million, and they are owned and run by 2.7 million people (URT, 2012). Tanzania is regarded as one of the rapidly emerging economies south of the Sahara in Africa, with a GDP growth rate of about 7\%. MSMEs are estimated to contribute $27 \%$ to this GDP (URT, 2012). These numbers provide justification for our focus on Tanzania.

Data for this study were obtained from a national survey on MSMEs in Tanzania. The objective of the survey ${ }^{3}$ was to provide a representative national baseline of the MSME segment in Tanzania so as to make statistically significant statements on a regional basis possible. The survey established Enumeration Areas (EAs) within the country, which were used to identify MSME owners for interviews. In each EA, a complete listing of households was made so as to identify all households that either currently owned and ran a small business or had done so previously. The respondents were required to be aged 16 and over (URT, 2012).

The data collection led to a total of 6,134 observations, representing a response rate of $98 \%$. In order to obtain a dataset of YOEs, we identified those respondents who, at the time of data collection (October 2010), were aged between 16 and 35 and owned and ran MSMEs. This left 3,098 observations, $51 \%$ of the original dataset.

The questionnaire that was administered to the respondents covered 20 different topics, with 192 questions focusing on the entrepreneurs' profile,

2 Information retrieved from the National Bureau of Statistics: www.nbs.go.tz

3 The survey was commissioned and funded by the Financial Sector Deepening Trust, hosted by the Ministry of Industry and Trade (MIT), in partnership with the National Bureau of Statistics, Steadman Associates (Synovate) and FinMark Trust South Africa, which provided technical assistance. 
business profile, markets, finance, management practices, business support services, business performance and livelihood demographics (URT, 2012).

For the purpose of our study, we understand that informational constraints may be an issue because it is possible that capable entrepreneurs may have better access to BDS services than incapable ones, and this could lead to a self-selection problem. However, this problem was reduced by the rigorous survey methodology applied (URT, 2012).

The definitions of enterprise categories adopted were based on those used by the Government of Tanzania and are summarized in Table 1 below.

Table 1. Government of Tanzania's categorization of business size

\begin{tabular}{lcc}
\hline Business size & Number of employees & $\begin{array}{c}\text { Capital investment in machinery } \\
\text { (Tanzanian Shillings) }\end{array}$ \\
\hline Micro enterprise & 1 to 4 & Up to 5 million \\
Small enterprise & 5 to 49 & Above 5 to 200 million \\
Medium enterprise & 50 to 99 & Above 200 to 800 million \\
Large enterprise & $100+$ & Above 800 million \\
\hline
\end{tabular}

Source: URT (2003).

\section{Variables and measures Dependent variables}

The dependent variables in this study are performance-related variables. Various performance measures are suggested in the literature. We use number of employees, defined as the logarithm of the number of employees of the enterprise at the time of the interview. The second dependent variable is financial records, measured as a binary variable equal to 1 if the enterprise keeps all business records in a book of accounts or ledger book and 0 otherwise. We also use perceived YOE performance, a binary variable equal to 1 if the young entrepreneur perceived his/her business as growing and 0 if constant or declining.

\section{Independent variables}

YOEs access a variety of BDS services. We selected four such services as our independent variables. First, expert advice is a binary variable equal to 1 if in the previous twelve months the enterprise had received any expert advice from outside the business to improve operations, performance and/ or productivity, and 0 otherwise. Business management training is a binary variable equal to 1 if the business (owner or any employee) was aware of and had received business management training, and 0 if not. Entrepreneurship training is a binary variable equal to 1 if the business (owner or any employee) 
was aware of and had received entrepreneurship training and 0 if not. Business plan development is a binary variable equal to 1 if the business had received support or assistance in developing a business plan and 0 otherwise. Technical skills training is a binary variable equal to 1 if the business owner had received related technical skills before or after starting the business and 0 otherwise (URT, 2012).

\section{Control variables}

We use a set of control variables related to the young entrepreneur and the enterprise in order to control for other effects. For the entrepreneurs, we use gender, defined as a binary variable equal to 1 if the entrepreneur is male and 0 if female. Education level is a binary variable equal to 1 if the entrepreneur has post-secondary education and 0 otherwise. For the YOE, we use the following: YOE age is the number of years from the year in which the enterprise started operations to the year of the interview (2010). We normalize this variable by taking its natural logarithm. Ownership is a binary variable equal to 1 if the business is owned by one person (sole proprietor) and 0 otherwise. Registration is a binary variable equal to 1 if the enterprise is registered with either the tax authority or the business registration and licensing authority and 0 otherwise. Business sector is a binary variable equal to 1 if the enterprise offers service related products such as retailing, wholesaling or consultancy, and 0 if the enterprise is involved in either manufacturing or agriculture.

\section{Model and analysis}

We performed three sets of analysis. First, we carried out a descriptive analysis of the profile of young entrepreneurs (Table 2 and Figure 1). This gave a picture of the type of youths that are running businesses. Next, we calculated summary statistics and performed correlation analyses of all the variables included in our study (Table 3 ). The objective was to understand our dataset and the nature of the variables by examining the means and standard deviations. Finally, we conducted an econometric analysis to test the hypothesis that there is a positive relationship between young entrepreneurs that have acquired BDS support and the performance of their enterprises. Here, we used regression analysis, the ordinary least squares method for the number of employees variable and probit regression for the financial records and perceived performance variables (Hair, Balck, Babin, Anderson and Tatham, 2008). Each independent variable was tested individually together with the control variables. The empirical model used to test the hypothesis was as follows: 
Performance of YOE (measured in number of employees, financial records and perceived YOE performance) $=$ constant $+{ }_{1}$ expert-advice $+_{2}$ businessmanagement-training+ ${ }_{3}$ entrepreneurship-training ${ }_{4}$ business-plandevelopment $+{ }_{4}$ technical-skills-training $+{ }_{4}$ control-variables $+E$

\section{RESULTS AND DISCUSSION}

\section{Profile of young entrepreneurs in Tanzania}

This section gives a brief profile of the young entrepreneurs in our dataset. We looked at their age, gender and education. As seen from Table 2, 73\% of the young entrepreneurs were between 25 and 35 years of age. Only $27 \%$ were aged between 16 and 25 . This may have two implications. First, as suggested by Chigunta (2002), the 16-25 age group contains both pre-entrepreneurs who are in transition from the security of the home or education to the workplace, and budding entrepreneurs who have started to run enterprises and are gaining some experience and skills. These entrepreneurs are still few in number and need more years to gain knowledge, skills and experience. The second implication is that it appears that youths in Tanzania finish their primary education at an older age than elsewhere in the world and are therefore late in starting businesses. This is also seen in Figure 1, which shows that $77 \%$ of the youths in our dataset had received primary education.

In addition, we found that (Figure 1) very few of the young entrepreneurs had been educated above primary level. This implies that most young entrepreneurs have a low level of education, which means they may not have enough skills and knowledge to run their enterprises successfully. As a result, BDS is even more necessary for these youths if their businesses are to grow and perform better. This result backs up the argument of Snee and Devine (2014) that youths' next step after school is influenced by the context in which they find themselves, and that the choices they make are shaped by structural and material constraints. In this case, the context of most youths in Tanzania is rural, and there are limited resources to support them in further studies.

In terms of gender, females dominate the sample, comprising $55.7 \%$ of the youths engaged in business in our sample. This is in line with the literature that indicates that more women are involved in owning and running SMEs (Carter and Allen, 1997; Mori, 2014; Stevenson and St-Onge, 2005). Also, 74\% of the youths are married. This suggests that youths get married at a younger age in Tanzania, forcing them to engage in running businesses to support their families (Nilan, 2008). 
Table 2 further shows that $67.7 \%$ of these youths are the main contributors to their families. This is supported by the fact that most of them run their business on a full-time basis ( $80.8 \%)$ and the business is their main source of income (61.1\%). These results support the literature that indicates that YOEs have a major impact not only on youth employment but also on economic and social development (Omundi, 2013).

Table 2. Profile of Young Entrepreneurs (Aged 16 to 35 years)

\begin{tabular}{|c|c|c|}
\hline & Percent & Obs. \\
\hline \multicolumn{3}{|l|}{ Age } \\
\hline $16-24$ & 26.50 & 3098 \\
\hline $25-35$ & 73.50 & 3098 \\
\hline \multicolumn{3}{|l|}{ Gender } \\
\hline Female & 55.70 & 3098 \\
\hline Male & 44.30 & 3098 \\
\hline \multicolumn{3}{|l|}{ Education Level } \\
\hline No education & 6.00 & 3098 \\
\hline Primary completed & 77.00 & 3098 \\
\hline Secondary completed & 13.00 & 3098 \\
\hline Technical education & 2.00 & 3098 \\
\hline University education & 2.00 & 3098 \\
\hline \multicolumn{3}{|l|}{ Marital Status } \\
\hline Single & 16.10 & 3098 \\
\hline Married/Partner & 74.90 & 3098 \\
\hline Divorced & 6.80 & 3098 \\
\hline Widowed & 2.10 & 3098 \\
\hline \multicolumn{3}{|l|}{ Economic Profile } \\
\hline Main income contributor in family & 67.80 & 3098 \\
\hline Running a business full time & 80.80 & 3098 \\
\hline This business is the main source of income & 61.10 & 3098 \\
\hline
\end{tabular}




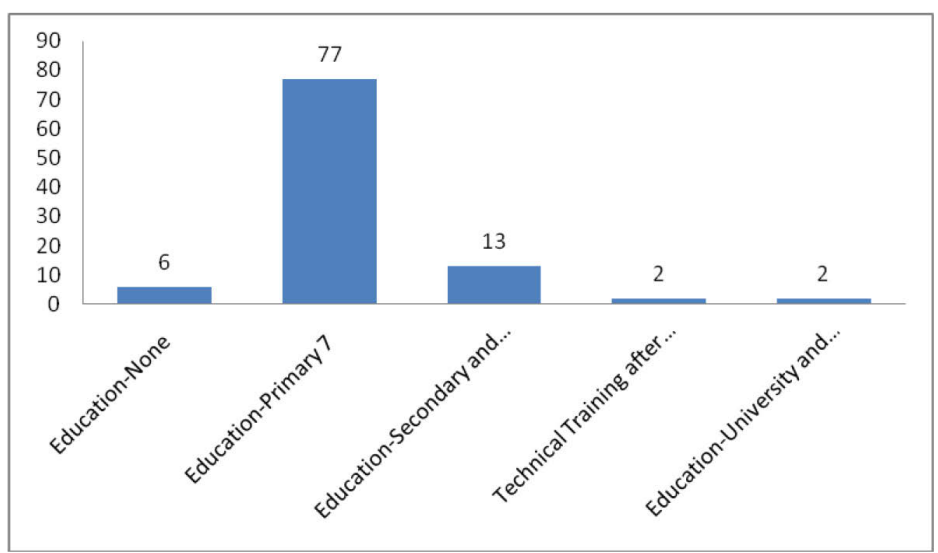

Figure 1. Young entrepreneurs and education level

\section{Summary statistics of variables in the study}

Table 3 shows the summary statistics of the variables included in this study. We used three different performance indicators as our dependent variables. We found the average number of employees of the YOEs to be 3. According to the MSME categorization, this means that most of the YOEs are micro enterprises with between 1 and 4 employees (URT, 2003). This further implies that youths are certainly generating employment for themselves but are yet to create employment for other youths. We also found that $45 \%$ of the youths kept financial records for their businesses. This is crucial because recent literature shows that most micro entrepreneurs do not tend to separate their business and household income; all income obtained from the business is combined and spent on household matters without proper records being kept. In our sample, $63 \%$ of the young entrepreneurs perceived their business to have grown since they had started it. This could be attributed to, among other factors, having access to BDS services which had helped change their attitude to self-employment and entrepreneurship.

In terms of the independent variables, namely capturing the use of BDS services, we found that $12 \%$ of the young entrepreneurs had received outside expert advice, including legal, accounting and auditing advice. We also found that only $6 \%$ of the youths had received business management training, $10 \%$ of the young entrepreneurs or their businesses had received entrepreneurship training, and $10 \%$ had received assistance with developing business plans. Technical skills training were the BDS service that had been accessed by the most youths in our dataset (14\%). This includes vocational training received by young entrepreneurs or their employees. In summary, we found that very few youths had been able to access BDS services. This 
supports the literature indicating that few SME owners are able to access such services, with negative effects on the performance of their enterprises (Chigunta, 2002).

The YOEs were quite young, with an average age of 3.7 years. $97 \%$ of the YOEs were sole proprietors and only $7 \%$ were registered with national registration authorities, meaning that the majority were informal. Only $29 \%$ of the YOEs were operating in the service sector, implying that the majority operated in the manufacturing sector.

Table 3. Summary statistics

\begin{tabular}{lcccc}
\hline & Percent & Obs. & Min & Max \\
\hline Dependent Variables & & & & \\
Number of employees & 2.00 & 2860 & 1.00 & 84.00 \\
Financial records & 45.00 & 3098 & 0.00 & 100.00 \\
Perceived YOE performance & 63.00 & 3098 & 0.00 & 100.00 \\
& & & & \\
Independent Variables & & & & \\
Expert advice & 12.00 & 3098 & 0.00 & 100.00 \\
Business management training & 6.00 & 3098 & 0.00 & 100.00 \\
Entrepreneurship training & 10.00 & 3098 & 0.00 & 100.00 \\
Business plan development & 10.00 & 3098 & 0.00 & 100.00 \\
Technical skills training & 14.00 & 3098 & 0.00 & 100.00 \\
& & & & \\
Control Variables & & & & \\
YOE age & 3.65 & 2560 & 0.50 & 12.56 \\
Ownership (sole proprietorship) & 97.00 & 1730 & 0.00 & 1.00 \\
Registration & 7.00 & 3090 & 0.00 & 1.00 \\
Business sector (service) & 29.00 & 1500 & 0.00 & 1.00 \\
\hline
\end{tabular}

\section{Correlation analysis}

Table 4 presents the correlations between the variables. First, we look at the correlations among the performance variables. As seen in the table, even though these variables are separate constructs, some of them are significantly related. For example, keeping financial records is significantly correlated with the number of employees (coefficient 0.09). Perceived performance is also significantly correlated with number of employees (coefficient 0.06) and financial records (coefficient 0.29). To reduce the combined effects 
on correlated dependent variables we ran separate regressions for each dimension.

The correlations between the dependent and independent variables provide the first simple test of our hypothesis and we see that a number of them are consistent with our hypothesis. First, the number of employees is positively and significantly correlated with technical skills (coefficient 0.14 ), YOE's age (coefficient 0.07 ) and registration status (coefficient 0.12). This implies that the enterprise is able to increase the number of employees when the owner receives technical skills training and when the enterprise grows and is registered. Keeping financial records is positively associated with several BDS service variables: expert advice (coefficient 0.07), business management training (coefficient 0.12), entrepreneurship training (coefficient 0.14 ) and business plan development (coefficient 0.16 ). Similarly, the young entrepreneurs perceived that their business performance had improved after they had received business management training (coefficient 0.11), entrepreneurship training (coefficient 0.09) and support for business plan development (coefficient: 0.12).

We are also aware of the possibility of multicollinearity among the independent variables. As seen in Table 4, the correlation coefficients among the independent variables are rather low, with the highest being between entrepreneurship training and business plan development (0.33). Kennedy (2008) holds that correlations need to be above 0.7 to indicate multicollinearity between the two variables. None of the coefficients is this high. In addition we calculated variance inflation factors (VIFs), which describe how much multicollinearity (correlation between independent variables) there is. Since none of these factors exceeds 5 , we can conclude that multicollinearity is not problematic in this study.

Table 4. Correlation analysis

\begin{tabular}{|c|c|c|c|c|c|c|c|c|c|c|c|c|c|c|c|}
\hline & & 2 & 3 & 4 & 5 & 6 & 7 & 8 & 9 & 10 & 11 & 12 & 13 & 14 & VIF \\
\hline 1 & $\begin{array}{l}\text { Number of em- } \\
\text { ployees }\end{array}$ & $0.09 *$ & $0.06 *$ & 0.06 & -0.01 & 0.03 & 0.02 & $0.14^{*}$ & $0.07^{*}$ & $-0.20 *$ & $0.12 *$ & 0.01 & $0.13^{*}$ & $0.09 *$ & \\
\hline 2 & $\begin{array}{l}\text { Financial re- } \\
\text { cords }\end{array}$ & & $0.29 *$ & $0.07 *$ & $0.12^{*}$ & $0.14^{*}$ & $0.16^{*}$ & 0.05 & 0.04 & -0.03 & $0.16^{*}$ & 0.01 & $0.22 *$ & $0.20 *$ & \\
\hline 3 & $\begin{array}{l}\text { Perceived YOE } \\
\text { performance }\end{array}$ & & & -0.01 & $0.11^{*}$ & $0.09 *$ & $0.12 *$ & 0.04 & 0.03 & -0.01 & $0.09 *$ & $-0.12^{*}$ & $0.11^{*}$ & $0.09 *$ & \\
\hline 4 & Expert advice & & & & $0.19 *$ & $0.14 *$ & $0.13^{*}$ & $0.09 *$ & 0.01 & 0.04 & $0.09 *$ & 0.03 & $0.04 *$ & $0.05^{*}$ & 1.18 \\
\hline 5 & $\begin{array}{l}\text { Business mana- } \\
\text { gement training }\end{array}$ & & & & & $0.44 *$ & $0.29 *$ & $0.24 *$ & -0.02 & -0.06 & $0.09 *$ & $0.23 *$ & 0.06 & 0.03 & 1.43 \\
\hline 6 & $\begin{array}{l}\text { Entrepreneur- } \\
\text { ship training }\end{array}$ & & & & & & $0.33^{*}$ & 0.30 & 0.03 & -0.03 & $0.12 *$ & 0.08 & 0.04 & 0.07 & 1.30 \\
\hline & $\begin{array}{l}\text { Business plan } \\
\text { development }\end{array}$ & & & & & & & $0.17^{*}$ & 0.08 & -0.01 & $0.22 *$ & $0.35^{*}$ & $0.18^{*}$ & $0.10^{*}$ & 1.34 \\
\hline
\end{tabular}




\begin{tabular}{|c|c|c|c|c|c|c|c|c|}
\hline 8 & $\begin{array}{l}\text { Technical skills } \\
\text { training }\end{array}$ & 0.02 & -0.05 & 0.05 & 0.07 & $-0.07 *$ & $0.16^{*}$ & 1.14 \\
\hline 9 & YOE age & & 0.01 & 0.02 & 0.03 & $0.08 *$ & $0.05^{*}$ & 1.15 \\
\hline 10 & Ownership & & & $-0.05^{*}$ & 0.06 & -0.04 & $-0.28 *$ & 1.16 \\
\hline 11 & Registration & & & & -0.08 & 0.08 & $0.12^{*}$ & 1.25 \\
\hline 12 & $\begin{array}{l}\text { Business sector } \\
\text { (service) }\end{array}$ & & & & & $-0.16^{*}$ & 0.08 & 1.06 \\
\hline 13 & Gender & & & & & & 0.04 & 1.06 \\
\hline 14 & Education level & & & & & & & 1.00 \\
\hline
\end{tabular}

$* p<0.05$

\section{Econometric results}

Does access to BDS services affect the performance of YOEs? To find out, we ran regressions between different types of BDS as the independent variables, and YOE performance. In order to see the effect of each type of BDS, we included each service variable in the regression, one at a time, running pooled OLS for the number of employees and probit regressions for financial record keeping and perceived performance. Table 5 presents the results, panel A for number of employees, panel B for financial record keeping and panel $C$ for perceived performance.

Generally, our results show that BDS services matter in terms of improving YOEs' performance. Panel A shows that expert advice and technical skills are significantly associated with more employees (coefficient $0.17, p<0.001$ ). This implies that access to these services is important in enabling an enterprise to grow (Matlay, Boter and Lundström, 2005). Panel B provides more support for our hypothesis. We can see that the ability to keep financial records is positively associated with obtaining expert advice (coefficient 0.81, $\mathrm{p}<0.001$ ), business management training (coefficient 0.69, $p<0.05$ ), entrepreneurship training (coefficient $0.57, p<0.001$ ) and support for business plan development (coefficient 0.671, $p<0.05$ ).

The literature shows that SMEs, including YOEs, are in most cases not trained or proficient in accounting or financial management, which means that most will need access to support services in order to gain expertise in and assistance with keeping financial business records (Berry et al., 2006). Our results provide evidence that those entrepreneurs who were able to access different types of BDS services and training were those who kept financial records. Being able to keep financial records is an important indicator that financial institutions use when offering loans to enterprises. Mori and Richard (2012), for example, show that one of the reasons why financial institutions find it difficult to lend to SMEs is their inability to keep 
proper financial records and their poor financial management. This challenge might be reduced if more YOEs were able to access BDS services.

Panel $C$ provides interesting results in terms of the associations between perceived performance and both business management and entrepreneurship training. The results are significantly positive for both (coefficient $0.69, p<0.05$; coefficient $0.35, p<0.05$, respectively). These results suggest that young entrepreneurs with exposure to such training perceive that their businesses are performing well, probably due to the nature of the training, which normally exposes participants to entrepreneurial tendencies, such as the need to achieve and be successful (De Gobbi, 2014; Kilonzo, 2012). In addition, this training helps participants to see their business as a success and contributes greatly to changing entrepreneurs' mindsets (Olomi, 2010). With this evidence, we argue that young entrepreneurs who have received training will perceive that their business is performing well because of a change in their mindset.

From these results, we can see that BDS services are a critical resource that YOEs need in order to improve their performance, both that of the young entrepreneurs themselves and that of their enterprises. The results reveal that no single BDS service influences all performance measures. We found that external advice affected the number of employees and the keeping of records. We found that business and entrepreneurship training affected financial record keeping and perceived performance. This implies that YOEs need to access a mixture of BDS services in order to build their competitive advantage. This is in line with Chigunta (2002), who suggests that young entrepreneurs need to access an integrated package of BDS services that include skills training, business counseling, mentor support, access to workspace, business expansion support, and the creation of support networks.

Table 5. Dependent variables regressed with BDS Services

Panel A: Ordinary Least Squares-Number of Employees (Ln)

Independent Variables

Expert advice

Business management training

Entrepreneurship training

Business plan development

Technical skills training

Control Variables

YOE age
1

$0.17^{* * *}$
2

$-0.41$

0.016 $\begin{array}{lll}3 & 4 & 5\end{array}$

$1.17^{* * *}$

Entrepreneurship: Intentions, Institutional and Process, Anna Ujwary-Gil, Krzysztof Klincewicz (Ed.) 


Ownership
Registration
Business sector
Education level
Gender
$\boldsymbol{N}$
adj. $\boldsymbol{R}^{2}$
Independent Variables
Expert advice
Business management training
Entrepreneurship training
Business plan development
Technical skills training

$\begin{array}{ccccc}-1.86 * * * & -6.47 * * * & -3.39 * * * & -10.38 * * * & -3.58 * * * \\ 0.70^{* * *} & 1.12^{* * *} & 1.11^{* * *} & 1.79 * * & 1.29 * * * \\ 0.03 & 0.04 & -0.04 & -0.03 & 0.10 \\ 0.01 & 0.01 & 0.01 & 0.01 & 0.01 \\ 0.18 * * * & 0.20 * & 0.12 & 0.14 & 0.14 \\ & & & & \\ 3095 & 531 & 1097 & 261 & 728 \\ 0.10 & 0.12 & 0.11 & 0.18 & 0.11\end{array}$

\section{Panel B: Probit Regression-Financial Records}

$\begin{array}{lllll}1 & 2 & 3 & 4 & 5\end{array}$
$0.81 * * *$
$0.69 * *$

$0.57^{* * *}$

$0.67^{*}$

Technical skills training

\section{Control Variables}

YOE age

0.01

$0.03^{*}$

$-0.01$

$0.03 \quad-0.01$

Ownership

$-0.16$

$-0.05$

$-0.22$

$-0.72$

$-0.56 * *$

Registration

Business sector

Education level

$0.81 * * *$

$0.75 * * *$

$0.89 * * *$

$1.19 * * * \quad 0.94 * * *$

0.04

0.04

0.11

$-0.09$

$0.20 * *$

$0.06 * * *$

0.04

$0.07 * * *$

0.05

$0.04 *$

Gender

$0.19 * * *$

0.18

$0.24 * * *$

0.30 *

0.17

N

$\begin{array}{lllll}3095 & 531 & 1097 & 261 & 728 \\ 0.14 & 0.12 & 0.23 & 0.08 & 0.10\end{array}$

Pseudo $\mathbf{R}^{2}$

Panel C: Probit Regression-Perceived Performance

\section{Independent Variables}

Expert advice

Business management training Entrepreneurship training

Business plan development

Technical skills training

$$
1
$$

2

3

$-0.15$

\section{Control Variables}

YOE age

Ownership

Registration

Business sector

Education level

$\begin{array}{ccccc}0.01 & 0.01 & 0.01 & 0.01 & 0.01 \\ -0.07 & 0.39 & -0.03 & -0.05 & 0.10 \\ 0.49 * * * & 0.52^{* * *} & 0.53^{* * *} & 0.57 * * & 0.54 * * * \\ -0.12 * & 0.04 & -0.10 & 0.20 & 0.05 \\ 0.02 & 0.01 & 0.05 * * & 0.05 & 0.03\end{array}$




\begin{tabular}{lccccc} 
Gender & 0.02 & 0.18 & -0.02 & 0.10 & 0.13 \\
$\mathbf{N}$ & & & & & \\
Pseudo. $\mathbf{R}^{2}$ & 3095 & 531 & 1097 & 261 & 728 \\
\hline
\end{tabular}

$* p<0.10, * * p<0.05, * * * p<0.01$

Our results provide support for the RBV, which argues that entrepreneurs build their businesses from the resources and capabilities they possess and acquire (Terziovski, 2010). BDS services are resources that, when an enterprise receives them either through the owner or the managers, help the enterprise to build a competitive advantage compared to other businesses.

The control variables also exhibit significant effects on YOEs. In terms of the enterprise's age, panel A shows a positive relationship between the enterprise's age and the number of employees. This is in line with Mori and Mersland (2014), who suggest that an enterprise's age matters for organizational growth. The results for ownership status suggest that sole proprietorship is negatively associated with YOEs' performance. We obtained negative significant results throughout all panels. This has two implications. Single-owner enterprises face the challenge of having limited managerial knowledge, experience and expertise available when making strategic, valuecreating decisions. This may result in limited growth and poor performance. In addition, Chittenden, Hall and Hutchinson (1996) argue that such enterprises are perceived to have high adverse selection problems. This would mean they would face a higher risk of not being funded by banks, hence limiting their performance. The registration variable also provides interesting results throughout all panels, with registration mattering to the performance of YOEs. Most SMEs in Tanzania are unregistered, implying that the entrepreneurs are limiting themselves when it comes to achieving high growth and good performance. The results further show that there are significant associations between being a male entrepreneur and performing well, especially with regards to keeping financial records and employing more people.

\section{CONCLUSION AND IMPLICATIONS}

This study examined the extent to which access to different forms of BDS services, as part of enterprises' critical resources, affects their performance. We focused on YOEs because youths form the basis of a society's future. The BDS services we examined were expert advice, business management training, entrepreneurship training, support with developing a business plan and technical skills. The performance measures examined were the number 
of employees, the keeping of financial records and perceived enterprise performance.

We used the RBV as our theoretical perspective because BDS forms part of the young entrepreneur's critical resources and is important for the performance of the enterprise. The theory further argues that differences in performance between YOEs are explained through differences in enterprises' human and financial assets and resources and their application, rather than through differences in industry structures. We therefore hypothesized that YOEs with access to BDS resources would perform better than those without. The empirical analysis was based on a MSME baseline dataset that was collected in 2010. The dataset covers the whole of Tanzania. We extracted data on young entrepreneurs between 16 and 35 years of age in 2010. The resulting youth dataset had 3,098 observations.

The results show support for a relationship between access to BDS and YOEs' performance. We found that access to expert advice was positively associated with YOEs' number of employees and their ability to keep financial records. We also found that business management and entrepreneurship training positively influenced financial record keeping and enterprises' perceived performance. Together, these results show that the resources young entrepreneurs obtain through accessing BDS services are important for their enterprises.

\section{Theoretical and practical implications}

A topic that has seen an escalation in research of late is youth employment and youth entrepreneurship (ILO, 2011; Schoof, 2006). This paper contributes to the youth entrepreneurship literature by showing the extent to which support for youth is important for enhancing economic and social development. Olomi and Nchimbi (2009) indicate that youth entrepreneurship and employment development should be looked at from the perspective of a varied set of interventions. They argue that such interventions should include, among others, the promotion of entrepreneurial values and skills, the imparting of business management and/or technical skills, and the provision of access to workspace, equipment, tools, facilities and technology, linkages to markets, professional services, business information, technology, finance, ongoing mentoring and counselling. These are also key resources that, according to the RBV, when provided to youths, are likely to enhance the performance of their enterprises ( $\mathrm{Ng}^{\prime}$ habi, 2013).

In addition, since most young entrepreneurs are poorly educated, it is important for them to access BDS as it is a crucial resource that will help build their entrepreneurial and business management capacity. Accessing BDS is 
also argued to be a third challenge (after finance and markets) that most SMEs face (Mori, 2014). Thus, it is important to understand the role that BDS plays in enhancing enterprises' performance.

Finally, Tanzania is one of the countries currently facing a high youth unemployment rate (Ng'habi, 2013). Improving our knowledge of how young people can engage in businesses successfully and provide employment for themselves and others may help to highlight the key capacities they need to be provided with so that economic development can be increased.

This study has several limitations. First, there is potential for reverse causality among the variables, which may lead to an endogeneity problem (Hermalin and Weisbach, 2003). Also there is a possibility of omitted variable bias, meaning that variables not included in this study could affect both the independent and dependent variables (Larcker and Rusticus, 2007). Endogeneity problems may be solved by means of instrumental variable methods. However, in the context in which this study was conducted and with the dataset available, we were unable to come up with a credible instrumental variable. For this reason, our results must be interpreted in terms of associations rather than causal relations. We do acknowledge, therefore, that conclusions from our study can only be drawn cautiously.

The other limitation of the study is the fact that it is based in Tanzania only, and the results may not be generalizable to the rest of the word. The study further lacks a deep knowledge of youth views and experiences of accessing BDS. A case study approach could be used to follow up on this study and address young entrepreneurs' opinions and experiences of how BDS services have affected their businesses.

\section{References}

Amorós, J. \& Bosma, N. (2013). Global Entrepreneurship Monitor: 2013 Global Report. GEM. Babson.

Barney, J. (1991). Firm Resources and Sustained Competitive Advantage.Journal of Management, 17(1), 99-120. doi: 10.1177/014920639101700108.

Berry, A., Sweeting, R. \& Goto, J. (2006). The effect of business advisers on the performance of SMEs. Journal of Small Business and Enterprise Development, 13(1).

Carter, N. \& Allen, K. (1997). Size determinants of women-owned businesses: choice or barriers to resources? Entrepreneurship \& Regional Development, 9(3), 211-220.

Chigunta, F. (2002). Youth Entrepreneurship: Meeting the Key Policy Challenges. Unpublished manuscript. Wolfson College, Oxford University, England.

Chittenden, F., Hall, G. \& Hutchinson, P. (1996). Small firm growth, access to capital markets and financial structure: Review of issues and an empirical investigation. Small Business Economics, 8(1), 59-67. 
De Gobbi, M. (2014). Making Youth Entrepreneurship Work in SubSaharan Africa: Some Factors of Success. Open Journal of Business and Management, 2, 305-313.

Fairlie R. (2005). Entrepreneurship and earnings among young adults from disadvantaged families. Small Business Economics 25: 223-236.

Garba, A. \& Djafar, F. (2013). Evidence of Opportunity and Necessity Driven Entrepreneurship in Nigeria. Journal of Entreprepreneurship, Management and Innovation, 9(3).

Green, F. (2013). Youth Entrepreneurship. Background paper for the OECD Centre for Entrepreneurship, SMEs and Local Development, OECD.

Hair, J., Balck, B., Babin, B., Anderson, R. \& Tatham, R. (2008). Multivariate Data Analysis (Vol. 6). Prentice Hall New Jersey

Hermalin, B. E. \& Weisbach, M. S. (2003). Board of Directors as an Endogeneously Determined Institution: A Survey of the Economic Literature (p. 25). Unpublished

ILO.(2011).YouthEntrepreneurshipFacility:Unleashing AfricanEntrepreneurship. Programme Document. International Labour Organization.

Kennedy, P. (2008). A guide to econometrics. Malden, MA: Blackwell Publishing.

Kilonzo, P. (2012). Policy and Strategic Options for Enhancing the Performance of Youth-Run Enterprises in Kenya. Investment Climate and Business Environment Research Fund. Accessed in August, 2014

Koe, W. (2013). Entrepreneurial Orientation (EO) and Performance of Government-Linked Companies (GLCs). Journal of Entreprepreneurship, Management and Innovation, 9(3), 20.

Larcker, D. F. \& Rusticus, T. O. (2007). Endogeneity and empirical accounting research. European Accounting Review, 16(1), 207-215.

Lerner, M. \& Almor, T. (2002). Relationships among Strategic Capabilities and the Performance of Women-Owned Small Ventures. Journal of Small Business Management, 40(2), 109-125. doi: 10.1111/1540-627x.00044.

Lewis, K. \& Massey, C. (2003). Delivering enterprise education in New Zealand. Education + Training, 45(4), 197-206.

Manacorda, M. \& Konydylis, F (2006). Youth in the Labor Market and the Transition from School to Work in Tanzania. Youth in Africa's Labor Market. Accessed in November, 2014

Matlay, H., Boter, H. \& Lundström, A. (2005). SME perspectives on business support services. Journal of Small Business and Enterprise Development, 12(2), 244-258. doi: doi:10.1108/14626000510594638.

Mori, N. (2014). Women Entrepreneurship Development in Tanzania. International Labour Organization.

Mori, N. \& Mersland, R. (2014). Boards in microfinance institutions: how do stakeholders matter? Journal of Management and Governance, 18(1), 1-29. doi: 10.1007/s10997-011-9191-4.

Mori, N. \& Richard, E. (2012). SMEs' Access to Financial Services: Tanzanian Bankers' Eye. Chinese Business Review, 11(2), 217-223. 
Mori, N. (2014). Women Entrepreneurship Development in Tanzania: International Labour Organization.

Ng'habi, S. (2013). Youth Entrepreneurship in Tanzania: Situation Analysis on Secondary Baseline Data for Youth Entrepreneurship Facility. ILO.

Niemelä, T. \& Häkkinen, R. (2014). The role of pluriactivity for continuity and survival in family farm firms. Journal of Entreprepreneurship, Management and Innovation, 10(4).

Nilan, P. (2008). Youth transitions to urban, middle-class marriage in Indonesia: faith, family and finances. Journal of Youth Studies, 11(1), 6582. doi: $10.1080 / 13676260701690402$.

Olomi, D. (2010). Survey of Barchelor of Commerce Graduates of the Univeristy of Dar es Salaam Business School. DANIDA: The Institute of Management and Entrepreneurship Development (IMED).

Olomi, D. \& Nchimbi, M. (2009). A Concept Note For Establishing Youth Entrepreneurship Centres in Zanzibar. International Labour Organization (ILO).

Omundi, P. (2013). Youth Enterprise: Inhibiting Factors and Opportunities. Africa Data and Information Network.

Peteraf, M. A. (1993). The cornerstones of competitive advantage: A resource-based view. Strategic Management Journal, 14(3), 179-191. doi: 10.1002/smj.4250140303.

Schoof, U. (2006). Stimulating Youth Entrepreneurship: Barriers and incentives to enterprise start-ups by young people. Small Enterprise Development Programme, ILO.

Shelley, A. (2014). Active Learning Innovations in Knowledge Management Education Generate Higher Quality Learning Outcomes. Journal of Entreprepreneurship, Management and Innovation, 10(1), 129-145.

Snee, H. \& Devine, F. (2014). Taking the next step: class, resources and educational choice across the generations. Journal of Youth Studies, 17(8), 998-1013. doi: 10.1080/13676261.2014.881987.

Stevenson, L. \& St-Onge, A. (2005). Support for Growth-oriented Women Entrepreneurs in Tanzania. Programme on Boosting Employment through Small Enterprise Development Job Creation and Enterprise Department, International Labour Organization (ILO).

Stevenson, L. \& St-Onge, A. (2013). National Assessment of Women's Entrepreneurship Development (WED) Framework Conditions: Assessors Guide. Women's Entrepreneurship Development Programme (ILO-WED) (pp. 155), ILO.

Sukarieh, M. \& Tannock, S. (2008). In the best interests of youth or neoliberalism? The World Bank and the New Global Youth Empowerment Project. Journal of Youth Studies, 11(3), 301-312. doi: $10.1080 / 13676260801946431$.

Terziovski, M. (2010). Innovation practice and its performance implications in small and medium enterprises (SMEs) in the manufacturing sector: a resource-based view. Strategic Management Journal, 31(8), 892-902. doi: $10.1002 /$ smj.841. 
URT - United Republic of Tanzania. (2003). SME Development Policy. Ministry of Industry and Trade (MIT).

URT - United Republic of Tanzania. (2007). National Youth Development Policy. Ministry of Labour and Youth Development.

URT - United Republic of Tanzania. (2012). National Baseline Survey Report for Micro, Small, and Medium Enterprises in Tanzania. Ministry of Industry and Trade (MIT).

Walstad, W. \& Kourilsky, M. (2008). Entrepreneurial Attitudes and Knowledge of Black Youth. Kauffman Centre for Entreprenerial Leadership.accessed online in November 2014.

Wanjiru, C. (2013). Factors Influencing the Performance of Youth Owned Micro and Small Enterprises: A Case of Kiambu. Unpublished manuscript, University of Nairobi, Kenya.

Wernerfelt, B. (1984). A Resource-Based View of the Firm. Strategic Management Journal, 5(2), 171-180.

\begin{abstract}
Abstrakt (in Polish)
W pracy zbadaliśmy próbę 3098 tanzańskich, losowo wybranych przedsiębiorstw należqacych do osób młodych (YOEs) oraz przestudiowaliśmy ich dostęp do usług wspierajqcych rozwój biznesu (BDS). YOEs definiuje się jako przedsiębiorstwa prowadzone przez młodych przedsiębiorców, w wieku od szesnastu do trzydziestu pięciu lat, zgodnie z obowiqzujqaca w Tanzanii definicja młodzieży. Przeanalizowaliśmy które usługi BDS wpływaja na wyniki działalności w zakresie: (i) liczby pracowników, (ii) czy przedsiębiorstwo prowadzi dokumentację finansowa i (iii) postrzegania przez przedsiębiorców efektywności ich przedsiębiorstw. Opierajqc sie na podejściu zasobowym (RBV), stwierdziliśmy, że dostęp do porad ekspertów jest pozytywnie powiqzzany z liczbq pracowników zatrudnianych w YOE i umiejętnościq prowadzenia ewidencji finansowej w tych przedsiębiorstwach. Zaobserwowaliśmy również, że dostęp do szkoleń w zakresie zarzqdzania i przedsiębiorczości pozytywnie wpływa na prowadzenie dokumentacji finansowej i postrzeganie wydajności przedsiębiorstw. Podsumowując, możemy stwierdzić, że środki, które młodzi przedsiębiorcy zyskujq poprzez dostęp do usług BDS sq kluczowe dla działalności ich przedsiębiorstw.
\end{abstract}

Słowa kluczowe: młodzież, usługi rozwoju biznesu, BDS, YOEs, Tanzania.

\title{
Biographical note
}

Dr. Neema Mori holds a PhD in International Management from the University of Agder, Norway; an MBA and BCom from University of Dar es Salaam, Tanzania. Currently, she is a Lecturer at Department of Finance of University of Dar es Salaam, Tanzania and a part time Postdoctoral researcher at the Norwegian Centre for Microfinance Research, University of Agder, Norway. Her research interests are in Microfinance, Corporate Governance of Small and Medium Enterprises and Entrepreneurial Finance. 
